\title{
UZNANIE ADMINISTRACYJNE A WYDANIE ZEZWOLENIA NA WYCIĘCIE DRZEW I KRZEWÓW
}

\section{ADMINISTRATIVE DISCRETION AND THE PERMISSION TO CUT OFF THE TREES AND SHRUBBERYS}

\section{STRESZCZENIE}

Uznanie administracyjne jest instytucją prawną umożliwiającą dostosowanie działań podejmowanych przez administrację publiczną do zmieniającej się rzeczywistości. Warunkiem wstępnym prawidłowego zastosowania tej instytucji jest jednak w pierwszej kolejności prawidłowe ustalenie $\mathrm{w}$ sprawie stanu faktycznego oraz prawnego, a następnie ustalenie, czy określona norma prawna daje organowi możliwość wyboru rozstrzygnięcia. W ramach instytucji zezwolenia na wycięcie drzew i krzewów uznanie organu pozwala mu na rozstrzy-

\footnotetext{
Absolwenci Uniwersytetu Mikołaja Kopernika w Toruniu.
} 
gnięcie, któremu z interesów - ogólnemu, czy też indywidualnemu, dać prymat w danej sprawie. W niniejszym artykule wskazano, czy, a jeżeli tak, to jakie, dyrektywy wyboru konsekwencji ustawodawca zawarł w ustawie o ochronie przyrody. Jednocześnie zaproponowano zmiany, które mogą ułatwić i uczynić bardziej przejrzystym proces wydawania/odmowy wydania zezwoleń na wycięcie drzew i krzewów.

\section{Słowa kluczowe}

Uznanie administracyjne-charakter instytucji, zezwolenie na wycięcie drzew i krzewów, dyrektywy wyboru konsekwencji.

\section{ABSTRACT}

Administrative discretion is a legal institution which gives organ a possibility to adjust activity entertain by it to changing conditions. Prerequsitie to valid use of abovementioned institution is to ascertain in a certain case a correct factual and legal state, and if certain provision gives a possibility to decide one of a admissible options. Administrative discretion in a situation in which authority has to decide about possibility to cut off trees or shrubberys is a situation in which organ has to decide which interest should be overriding - individual or public. In this article we indicate what suggestions about the way in which certain case should be resolved could be found in Law of environmental protection. We also propose solutions, which in our opinion should simplify and lucid foregoing institution.

\section{Keywords}

Administrative dicretion-character of the institution, permission to cut off tress and shrubberys, directives of consequences.

\section{WSTĘP}

Uznanie administracyjne jako instytucja prawa administracyjnego jest uważana $\mathrm{w}$ doktrynie jako jedna $\mathrm{z}$ istotniejszych kwestii nauki prawa administracyjnego. Powyższy pogląd wynika z faktu, że na kształt tej instytucji z jednej strony wpływa idea 
związania organów administracji publicznej przepisami prawa, z drugiej natomiast strony konieczność zapewnienia organom administracji publicznej niezbędnej elastyczności umożliwiającej im podejmowanie adekwatnych działań do zmieniającej się rzeczywistości ${ }^{1}$. Celem niniejszego artykułu jest przedstawienie instytucji uznania administracyjnego $\mathrm{w}$ praktyce stosowania przepisów ustawy o ochronie przyrody ${ }^{2}$, dotyczących zezwolenia na wycięcie drzew i krzewów.

\section{UZNANIE ADMINISTRACYJNE}

Dyskrecjonalność jest elementem nieuniknionym w działaniu administracji ${ }^{3}$. Można stwierdzić, iż zjawisko to jest niezależne od prawodawcy. Występują pewne „naturalne” źródła swobody decyzyjnej. Po pierwsze, jest nim sama właściwość języka prawnego, polegająca na wieloznaczności i nieostrości pojęć, która wywołuje potrzebę zastosowania reguł wykładni i nie sprzyja wydawaniu jednolitych decyzji. Po drugie, duża ilość przepisów prawnych powiązanych ze sobą na płaszczyźnie poziomej i pionowej, prowadząca do luk oraz kolizji. Po trzecie, zmiany zachodzące w społecznym otoczeniu prawa. Po czwarte wreszcie, sam sposób stosowania prawa objawiający się bardzo często w redukcji ogólnej normy do prawnej podstawy konkretnej decyzji w powiązaniu z danym stanem faktycznym. Dyskrecjonalność w stosowaniu praw może być ujęta w perspektywie całej praktyki decyzyjnej oraz w perspektywie konkretnej decyzji stosowania prawa. W obu przypadkach pozostaje w związku z wartością jednolitości stosowania prawa oraz oznacza sytuacje

1 M. Jaśkowska, Uznanie administracyjne $w$ orzecznictwie sadów administracyjnych, „Zeszyty Naukowe Sądownictwa Administracyjnego" 2010, nr 5-6, s. 168.

2 Ustawa z dnia 16 kwietnia 2004 r. o ochronie przyrody, Dz.U. z 2004 r. Nr 92, poz. 880 ze zm.; dalej: u.o.p lub ustawa).

3 Zob. J. Zimmermann, Znaczenie uzasadnienie rozstrzygnięcia organu administracji publicznej dla orzecznictwa sądowo administracyjnego, „Zeszyty Naukowe Sądownictwa Administracyjnego" 2010, nr 5-6, s. 517. 
„swobody od” (niezależności od) czegoś,co tę dyskrecjonalność przynajmniej potencjalnie, ogranicza ${ }^{4}$. Wskazane powyżej czynniki niewątpliwie wpływają na proces stosowania prawa i wywierają wpływ na każdym jego etapie, a w ostateczności na kształt rozstrzygnięcia podejmowanego przez organ administracji publicznej. Jednakże z uznaniem administracyjnym będziemy mieli do czynienia wówczas, gdy administracja dla urzeczywistnienia stanu prawnego może wybierać między różnymi rozwiązaniami. Uznanie występuje wtedy, gdy norma prawna nie determinuje w sposób jednoznaczny skutku prawnego, lecz pozostawia w sposób wyraźny dokonanie takiego wyboru organowi administracyjnemu. Inaczej mówiąc, ustawa pozwala na wybór następstwa prawnego, przy czym można dokonywać wyboru między dwiema lub więcej możliwościami ${ }^{5}$.

Powyższa konstatacja oznacza, iż uwzględniając zaproponowane przez Jerzy Wróblewskiego model stosowania prawa, składający się z czterech etapów: wykładani prawa, ustalenia stanu faktycznego, subsumcji oraz wiążącego ustalenie jej konsekwencji prawnych ${ }^{6}$, z uznaniem administracyjnym będziemy mieli do czynienia dopiero na ostatnim z wyżej wskazanych etapów. Warunkiem stosowania uznania administracyjnego jest zatem prawidłowe działanie organu na wcześniejszych etapach stosowania prawa, polegające na należytym ustaleniu stanu faktycznego, wyborze normy prawnej oraz poprawnym dokonaniu subsumcji. Uznanie administracyjne nie może zatem wpływać na interpretację przepisów prawa oraz na dokonywanie ustaleń faktycznych ${ }^{7}$.

4 L. Leszczyński, Dyskrecjonalność, a jednolitość stosowania prawa. Rola argumentu per rationem decidendi, [w:] W. Staśkiewicz, T. Stawecki, Dyskrecjonalność $w$ prawie, Warszawa 2010, s. 140.

5 E. Ochendowski, Prawo administracyjne - część ogólna, Toruń 2009, S. 210.

6 J. Wróblewski, Sądowe stosowanie prawa, Warszawa 1972, s. 50-57.

7 Por. wyrok WSA w Poznaniu z dnia 7 maja 2008 r., IV SA/Po 99/08, CBOSA, gdzie zauważono, że uznanie administracyjne dotyczy przyszłości; przedmiotem uznania nie jest ustalenie znaczenia tekstu prawnego ani ocena występujących faktów, lecz określenie skutku prawnego. 
Badając zwroty, które mogą stanowić o upoważnieniu organu do zastosowania instytucji uznania, nie można zapominać, że mogą pełnić one funkcję pomocniczą przy podejmowaniu decyzji. Przepisy w rozmaity sposób formułują upoważnienia do uznania. Najczęściej spotyka się tu sformułowania typu „może”. Niejednokrotnie termin ten bywa sprzężony z innymi terminami sugerującymi samo przez się możliwość wyboru, np. występuje często sformułowanie „może zezwolić” czy „może uznać”. Konsekwencjami, jakie wynikają z przyjęcia tego typu rozwiązań prawodawczych, jest nadanie organowi administracji prawa do udzielania zezwolenia bądź też jego odmowy. Ponadto należy stwierdzić, że istnieje wreszcie pewna grupa terminów, które tradycyjnie uważano za upoważnienie do uznania, a które samo przez się niczego jeszcze nie oznaczają. Do tej grupy zaliczają się różne „zezwolenia” czy „pozwolenia”. W każdym przypadku użycia przez ustawodawcę takich terminów należy starać się znaleźć odpowiedź na pytanie, czy w określonych warunkach organ jest zobowiązany wydać takie zezwolenie, czy też może, ale nie musi tak postąpić9

Wreszcie należy zauważyć, iż prawodawca posługując się tzw. dyrektywami wyboru konsekwencji, może wskazywać organowi administracji publicznej, jakie czynniki winien uwzględnić on przy wyborze następstw prawnych danego rozstrzygnięcia ${ }^{10}$. W doktrynie wskazuje się, że do dyrektyw wyboru konsekwencji należą: dyrektywy faktyczne - wskazują na fakty, jakie organ zobowiązany jest uwzględnić; dyrektywy odsyłające - odsyłają do pewnych norm lub zasad; dyrektywy kierunkowe - wskazujące na konieczność uwzględnienia pewnych wymogów celowościowych z zakresu gospodarki, polityki etc ${ }^{11}$.

Dodatkowo należy również zwrócić uwagę, że na swobodę wyboru konsekwencji prawnych organu wpływ mają także

8 M. Mincer, Uznanie administracyjne, Toruń 1983, s. 81.

9 Ibidem, s. 82.

10 Ibidem, s. 63.

11 Ibidem, s. 91-92. 
przepisy kodeksu postępowania administracyjnego ${ }^{12}$, co podkreśla się zarówno w doktrynie, jak i judykaturze. Organ administracji jest bowiem ograniczony regulacjami w nim zawartymi. Zwłaszcza art. 7 odgrywa w tym zakresie istotną rolę. W przypadku rozstrzygania $\mathrm{w}$ przedmiocie wydania zezwolenia organ administracji powinien kierować się kryteriami wynikającymi z tego przepisu, czyli zarówno słusznym interesem społecznym, jak i słusznym interesem stron ${ }^{13}$. Jeżeli w sprawach pozostawionych przez przepisy uznaniu administracyjnemu interes społeczny nie stoi temu na przeszkodzie i leży to w możliwości organu administracji, organ ten ma obowiązek załatwić sprawę w sposób pozytywny dla strony. Tworzy się w ten sposób zatem domniemanie pozytywnego rozstrzygnięcia dla strony, chyba że brak jest realnych możliwości, by takie rozstrzygnięcie nastąpiło. Niemożliwość taka może wynikać z przyczyn faktycznych albo gdy pozytywnemu rozstrzygnięciu stoi na przeszkodzie niebudzący wątpliwości interes ogólny. Także przepis art. 107 kpa, ustanawiający obowiązek zawarcia w każdej decyzji m.in. uzasadnienia faktycznego oraz prawnego limituje przysługującą organowi swobodę. W związku z powyższym można stwierdzić, że uznanie administracyjne - stanowiące pewną ściśle określoną sferę swobody pozostawionej przez ustawę - nie stanowi w żaden sposób uprawnienia dla organu do podejmowania dowolnego działania ${ }^{14}$. Domniemanie pozytywnego rozstrzygnięcia dla strony oraz konieczność uzasadnienia przyjętego stanowiska stanowią skuteczne narzędzia ograniczenia swobody organu.

12 Ustawa z dnia 14 czerwca 1960 r. Kodeks postępowania administracyjnego, tj. Dz.U. z 2000 r. Nr 98, poz. 1071 z późn. zm.; dalej: kpa).

13 K. Gruszecki, Zezwolenie na usunięcie drzew i krzewów, Wrocław 2011, s. 170 .

14 Zob. W. Jakimowicz, Wykładnia $w$ prawie administracyjnym, Kraków 2006, s. 144 i wskazane tam orzecznictwo. 


\section{INSTYTUCJA ZEZWOLENIA NA WYCIĘCIE DRZEW I KRZEWÓW}

Odnosząc się do instytucji zezwolenia na wycięcie drzew i krzewów, należy zauważyć na wstępie, że została ona umiejscowiona w ustawie o ochronie przyrody, co oczywiście nie stanowiło przypadkowego działania ustawodawcy. Ochrona środowiska stanowi bowiem obowiązek władz publicznych. Wniosek ten wypływa z art. 74 Konstytucji Rzeczypospolitej Polskiej, który stanowi między innymi, że władze publiczne prowadzą politykę zapewniającą bezpieczeństwo ekologiczne współczesnemu i przyszłym pokoleniom (ust. 1), a ochrona środowiska jest obowiązkiem władz publicznych (ust. 2) ${ }^{15}$. Jak zauważa się przy tym w doktrynie rola tego obowiązku istotnie wzrasta w ostatnich latach ${ }^{16}$.

Obowiązek władz publicznych, o którym mowa powyżej, można rozpatrywać w opozycji do art. 64 ust. 1 i 2 Konstytucji, z którego wynika, że każdy ma prawo do własności podlegającej przy tym równej dla wszystkich ochronie prawnej. Sama już bowiem Konstytucja w wyżej wymienionym przepisie (art. 64 ust. 3) dopuszcza ograniczenie tego prawa w odpowiednim zakresie i formie. Jak trafnie zauważył Trybunał Konstytucyjny w swoim wyroku z dnia 25 maja 1999 r. ${ }^{17}$, prawo własności, najpełniej zdefiniowane $\mathrm{w}$ art. $140 \mathrm{kc}$, ograniczone jest $\mathrm{z}$ jednej strony przez zasady współżycia społecznego, z drugiej natomiast podlega różnorakim ograniczeniom przewidzianym przez ustawy, wśród których najliczniejszą grupę stanowią normy administracyjnoprawne. Jak konstatuje zatem TK, właścicielowi wszystko wolno, czego mu ustawa i wzgląd na uzasadnione interesy innych osób nie zabraniają. Prawo własności nie daje

15 Na temat zakresu pojęcia „środowiska” zobacz art. 3 pkt 39 Ustawy z dnia 27 kwietnia 2001 r. Prawo ochrony środowiska (Dz.U. 2001 Nr 62, poz. 627 z późn. zm.).

16 W. Skrzydło, Konstytucja Rzeczypospolitej Polskiej, Warszawa 2009, s. 89.

17 Wyrok TK z dnia 25 maja 1999 r., SK 9/98, Z.U. 1999, Nr 4, poz. 78. 
zatem właścicielowi pełnej, absolutnej władzy nad rzeczą - nie jest już ius infinitum. W rzeczywistości stwierdza TK, że granice prawa własności są takie, jakie zakreśla całokształt przepisów konkretnego ustawodawstwa.

Przykładem ograniczenia prawa własności jest właśnie przewidziana w u.o.p instytucja zezwolenia na wycięcie drzew i krzewów. Jak wskazano w literaturze, „nie ulega wątpliwości, że zakaz usuwania drzew i krzewów z własnej (a tak jest z reguły) nieruchomości bez zezwolenia organu administracji publicznej (inaczej mówiąc - wymóg uzyskania zezwolenia) jest ograniczeniem chronionego konstytucyjnie (art. 64 Konstytucji RP) prawa wykonywania własności"18. Wyżej wspomnianemu ograniczeniu odpowiada również art. 31 ust. 3 Konstytucji. Przepis ten stanowi bowiem, że ograniczenia w zakresie korzystania z konstytucyjnych wolności i praw mogą być ustanowione tylko w ustawie i tylko wtedy, gdy są konieczne w demokratycznym państwie dla jego bezpieczeństwa lub porządku publicznego, bądź dla ochrony środowiska, zdrowia i moralności publicznej, albo wolności i praw innych osób. Ograniczenia te nie mogą naruszać istoty wolności i praw. Jak podniesiono w orzecznictwie przepis art. 31 ust. 3 Konstytucji stanowi jednoznaczną i wyraźną konstytucyjną podstawę dla wprowadzania ograniczeń prawa własności, w tym - co jest istotne dla rozpatrywanej sprawy - ograniczeń koniecznych dla ochrony środowiska. Konstytucja do problematyki ochrony środowiska nawiązuje kilkakrotnie na gruncie szeregu swoich przepisów. W art. 5, zamieszczonym w rozdziale 1 Konstytucji „Rzeczpospolita”, postanawia, że Rzeczpospolita Polska zapewnia ochronę środowiska, kierując się zasadą zrównoważonego rozwoju. Z uwagi na istotę tej problematyki ochronę środowiska Konstytucja traktuje także w kategorii obowiązku obywatelskiego, o czym stanowi art. 86 Konstytucji. Zasady odpowiedzialności, jakie spoczywają na obywatelach, określa ustawa ${ }^{19}$. Zgodnie z powyższymi prze-

18 W. Radecki, Ustawa o ochronie przyrody. Komentarz, Warszawa 2008, s. 245.

19 Zob. wyrok WSA w Krakowie z dnia 04.06.2009 r., II SA/Kr 324/09, dostępny w CBOSA. 
pisami ograniczenie w zakresie korzystania z prawa własności zostało ustanowione $\mathrm{w}$ ustawie oraz odpowiada konieczności dbania o ochronę środowiska. Ograniczenie to jest również zgodne z treścią Protokołu nr 1 Europejskiej Konwencji o Ochronie Praw Człowieka i Podstawowych Wolności, który stanowi w art. 1, że ochrona własności przewidziana w tym akcie prawnym nie narusza w żaden sposób prawa państwa do stosowania takich ustaw, jakie uzna za konieczne do uregulowania sposobu korzystania z własności zgodnie z interesem powszechnym lub w celu zabezpieczenia uiszczania podatków bądź innych należności lub kar pieniężnych ${ }^{20}$. Tym samym, w świetle postanowień protokołu dopuszczalne jest stanowienie przez państwo stronę ustaw, jakie uzna za konieczne w procesie regulacji korzystania z prawa własności, jeżeli tylko dana ustawa jest zgodna $\mathrm{z}$ interesem powszechnym. Postawienie wymogu uzyskania zezwolenia na usunięcie własnego drzewa mieści się zatem, jak stwierdza Wojciech Radecki, w regulacjach Protokołu ${ }^{21}$.

\section{PRZYCZYNY UZNANIOWEGO CHARAKTERU DECYZJI ADMINISTRACYJNEJ W ZAKRESIE WYDANIA ZEZWOLENIA} NA USUNIĘCIE DRZEW I KRZEWÓW NA TLE ART. 83 UST. 3 USTAWY O OCHRONIE PRZYRODY

Odnosząc powyższe rozważania na temat uznania administracyjnego do instytucji zezwolenia na wycięcie drzew/krzewów należy w pierwszej kolejności skoncentrować swoją uwagę na art. 83 ust. 1 i 3 u.o.p. Decyzja wójta, burmistrza albo prezydenta zapadająca po rozpoznaniu wniosku o zezwolenie na usunięcie drzew lub krzewów może w szczególności obejmować udzielenie takiego zezwolenia lub odmowę jego udzielenia. To

20 Protokół ratyfikowany przez Rzeczpospolitą Polskę, opublikowany w Dz.U. z 1995 r. Nr 36, poz. 175.

21 W. Radecki, Ustawa..., s. 246. 
pierwsze, pozytywne rozstrzygniecie sprawy, może z kolei przybrać postać zezwolenia prostego (to znaczy niezawierającego warunku) lub uwarunkowanego, jak wskazuje ustawa: przesadzeniem drzew lub krzewów w miejsce wskazane przez wydającego zezwolenie albo zastąpienie innymi drzewami lub krzewami w liczbie nie mniejszej niż liczba usuwanych. Przesadzenie lub zastąpienie jest warunkiem $\mathrm{w}$ rozumieniu art. $162 \S 1$ pkt 2 kpa, co oznacza, że niedopełnienie warunku pociąga za sobą stwierdzenie wygaśnięcia decyzji. Warunek o którym mowa $\mathrm{w}$ ww. przepisie to warunek $\mathrm{w}$ rozumieniu przepisów prawa cywilnego (art. 89 kc). Tym samym utrzymanie w mocy decyzji uzależnione jest od zdarzenia przyszłego i niepewnego ${ }^{22}$. We wszystkich omówionych powyżej konfiguracjach decyzja ma charakter uznaniowy. Nie da się zatem z u.o.p., jak trafnie stwierdza W. Radecki, wywnioskować publicznoprawnego roszczenia o zezwolenie na usunięcie drzew lub krzewów ${ }^{23}$.

W tym kontekście należy jednak podkreślić, że w świetle art. 86 wyżej wymienionej ustawy, w sytuacji, w której ustawodawca rezygnuje z opłat za usuwanie drzew i krzewów, organ powinien obligatoryjnie wydać zezwolenie, jeżeli interes społeczny nie przemawia za utrzymaniem drzew i krzewów. Co więcej, wydanie przez organ zezwolenia na usunięcie drzew i krzewów jest wyjątkiem od zasady nakazującej utrzymanie drzew i krzewów we właściwym stanie. Dodatkowo, możliwość pozostawiona przez ustawodawcę, a polegająca na przesadzeniu drzew lub krzewów bądź na zastąpieniu ich innymi drzewami lub krzewami w odpowiedniej liczbie stanowi podstawę do twierdzenia, że rozstrzygnięcie ma charakter limitowanego uznania administracyjnego ${ }^{24}$. Ograniczenie wskazanego luzu decyzyjnego, jaki ma organ podczas rozstrzygania wskazanych kwestii, zdaje się potwierdzać coraz częściej wysuwaną przez doktrynę tezę o odchodzeniu od pojęcia „uznania” bądź

22 M. Jaśkowska, A. Wróbel, Komentarz aktualizowany do art. 162 kodeksu postępowania administracyjnego - System informacji prawnej LEX.

23 W. Radecki, Ustawa..., s. 248-249.

24 A. Majewski, Kryteria wydawania przez organy gmin zezwoleń na usunięcie drzew i krzewów, „Samorząd Terytorialny” 1996, nr 11, s. 57. 
„swobodnego uznania” i zastępowaniu go przez pojęcie „ograniczonego swobodnego uznania". Fakt ten wyraźnie daje się zauważyć poprzez możliwości wyboru przez organ konkretnego rozwiązania zastępczego spośród tylko dwóch wskazanych w art. 83 ust. 3 u.o.p. aspektów. Powstaje zatem jak stwierdza A. Majewski „konieczność rozważenia granicy pomiędzy obszarem, w którym rozstrzygnięcie organu gminy wyznaczone jest normami prawnymi a obszarem rozstrzygnięcia, który norma prawna przekazuje do uznania organowi, oraz dyrektyw, którymi powinien kierować się organ przy uznaniu"25.

\section{DYREKTYWY WYBORU KONSEKWENCJI W ŚWIETLE ORZECZNICTWA}

Biorąc pod uwagę poczynione wcześniej rozważania dotyczące ochrony środowiska oraz uzyskania zezwolenia na wycięcie drzew i krzewów w kontekście prawa własności i jego ograniczenia, interesująca będzie dalsza analiza zagadnienia uznaniowości decyzji organu administracji w zakresie wydania zezwolenia na wycięcie drzew i krzewów. Powstaje bowiem sytuacja, w której z jednej strony ustawodawca w celu ochrony przyrody dokonał ingerencji $\mathrm{w}$ konstytucyjne prawo własności. Z drugiej natomiast strony faktem jest, że przesłanki, które powinien wziąć organ pod uwagę przy ingerowaniu $\mathrm{w}$ prawo własności, nie zostały przez ustawodawcę określone. Niewątpliwie wpływ na to ma fakt, że trudno wymagać od ustawodawcy uwzględnienia $\mathrm{w}$ treści przepisów wszystkich możliwych sytuacji, jakie w czasie obowiązywania określonego aktu prawnego będą miały miejsce ${ }^{26}$.

Tym istotniejsze wydaje się zatem rozważenie sposobów wypełniania przez organ wspomnianego wyżej luzu pozostawionego przez normę prawną, czyli scharakteryzować uznanio-

25 A. Majewski, Kryteria..., s. 57.

26 E. Ochendowski, Prawo..., s. 207. 
wy charakter decyzji organu administracji w sprawie wydania zezwolenia na wycięcie drzew i krzewów.

Obowiązująca obecnie ustawa o ochronie przyrody nie stanowi w swojej treści ogólnych dyrektyw, które powinien brać pod uwagę organ przy wydawaniu decyzji o charakterze uznaniowym w kwestii usunięcia drzew i krzewów. Mogłyby one stanowić swoistego rodzaju fundament do podjęcia decyzji prostej lub uwarunkowanej. Posługując się jednak regułami wykładni funkcjonalnej oraz systemowej, które przychodzą nam w tej sytuacji z pomocą, należy wskazać za Krzysztofem Gruszeckim, że „na gruncie - poprzednio regulującej tę problematykę - art. 48 ustawy o ochronie i kształtowaniu środowiska stwierdzono, że zezwolenia na usuwanie drzew i krzewów mają charakter dyskrecjonalny. Nie mogą jednak pozostawać w sprzeczności z: obowiązującymi zasadami prawa, postanowieniami konstytucji, przepisami zawierającymi normy powszechnie obowiązujące i podlegającymi bezpośrednio zastosowaniu $\mathrm{w}$ danej sprawie normami międzynarodowymi, ustawą wprowadzającą wymóg uzyskania zezwolenia, ustawami szczególnymi, innymi powszechnie obowiązującymi przepisami prawa"27. Ponadto, w orzecznictwie sądów administracyjnych wskazano szereg wskazówek, którymi powinien kierować się organ, rozpatrując wniosek o wydanie zezwolenia na wycięcie drzew lub krzewów.

I tak, Wojewódzki Sąd Administracyjny w Poznaniu w wyroku z dnia 29.07.2009 $\mathrm{r}^{28}$ wskazał, iż zgodnie z art. 7 kpa organ winien załatwić sprawę, mając na względzie interes społeczny i słuszny interes obywateli. Z tej przyczyny organ działając w ramach uznania - winien przeprowadzić wnikliwe postępowanie zmierzające do oceny stwierdzonego stanu faktycznego, jako że konstrukcja przepisów dotyczących wydawania zezwoleń na wycięcie drzew nie wyklucza możliwości odmowy uwzględnienia wniosku lub orzeczenia w sposób odbiegający od sprecyzowanego w nim żądania, jednakże nakłada na organ obowiązek każdorazowego precyzyjnego wskazania

27 K. Gruszecki, Ustawa o ochronie przyrody. Komentarz, Kraków 2005, s. 325 .

28 Wyrok WSA w Poznaniu z dnia 29.07.2009 r., II SA/Po 42/09, CBOSA. 
przesłanek, jakimi kierował się, wydając decyzję. Działanie organu $\mathrm{w}$ ramach uznania administracyjnego obliguje zatem organ do podania uzasadnienia prawnego i faktycznego podjętego rozstrzygnięcia, co wynika z jednej strony z obowiązującej w postępowaniu administracyjnym zasady przekonywania (art. $11 \mathrm{kpa}$ ), z drugiej zaś z obowiązku umożliwienia sądowi przeprowadzenia kontroli legalności. Wojewódzki Sąd Administracyjny w Warszawie w wyroku z dnia 09.07.2008 r. ${ }^{29}$ podkreślił natomiast, że orzekając w przedmiocie zezwolenia na wycięcie drzew lub krzewów organ musi uwzględniać również właściwe $\mathrm{w}$ danej sprawie przepisy prawa materialnego, tj. na gruncie rozstrzyganej sprawy przepisy ustawy o ochronie przyrody. Zgodnie bowiem $\mathrm{z}$ tym aktem prawnym ochrona przyrody w rozumieniu art. 2 ust. 1 pkt 7, 8 i 9 ustawy polega na zachowaniu, równoważnym użytkowaniu oraz odnawianiu zasobów, tworów i składników przyrody: krajobrazu, zieleni w miastach i wsiach oraz zadrzewień, a celem ochrony przyrody - stosownie do art. 2 ust. 2 pkt 5 i 7 przedmiotowej ustawy - jest ochrona walorów krajobrazowych, zieleni w miastach i wsiach oraz zadrzewień, nadto kształtowanie właściwych postaw człowieka wobec przyrody przez edukację, informowanie i promocję w dziedzinie ochrony przyrody.

Opierając się na wyżej wskazanych przesłankach, najistotniejszą kwestią wydaje się wyważenie interesu obu stron procesu decyzyjnego. Postępowanie to powinno brać przede wszystkim pod uwagę interes prawny oraz faktyczny podmiotu wnioskującego przy jednoczesnym rozważeniu interesu publicznego przemawiającego za pozostawieniem jak największej liczby obiektów przyrodniczych. Organ decyzyjny powinien brać pod uwagę w szczególności kwestie, czy bez zezwolenia, o które wnioskuje podmiot, nie można zrealizować danego przedsięwzięcia dającego asumpt do wystąpienia o zezwolenie na wycięcie, jednocześnie badając konsekwencje takiego zezwolenia dla środowiska.

29 Wyrok WSA w Warszawie z dnia 09.07.2008 r., IV SA/Wa 694/08, CBOSA. 
Ponadto organ powinien zbadać, czy nie będzie wystarczające spełnienie warunków art. 83 ust 3 u.o.p. Warto przy tym zauważyć, że jak słusznie podnosi się w orzecznictwie ${ }^{30}$, z ww. przepisu wynika, iż organ administracji rozpatrując wniosek o wydanie zezwolenia na usunięcie drzew lub krzewów, może uzależnić wydanie takiego zezwolenia od zastąpienia wyciętych drzew innymi drzewami. Podkreślić przy tym należy jednak, iż przepis ten nie daje organowi umocowania do określenia gatunku, wieku oraz parametrów drzew (obwodu pnia, wysokości, czy też innych cech), jakie mają być nasadzone. Jedynym bowiem uprawnieniem organu w przypadku zastosowania tego przepisu jest nałożenie na stronę obowiązku nasadzenia określonej (nie mniejszej niż liczba usuwanych) liczby drzew lub krzewów w miejsce usuwanych.

Dopiero wskazanie negatywnych wniosków wynikających z przeprowadzonych rozważań odnośnie do możliwości wydania decyzji zezwalającej na wycięcie drzewa lub krzewów (warunkowej lub też nie) umożliwia organowi wydanie decyzji odmownej. Jak przy tym podnosi się w doktrynie, za wystarczającą przesłankę do wydania decyzji odmawiającej zezwolenia na usunięcie drzew lub krzewów nie może być uznany sam walor przyrodniczy obiektu objętego wnioskiem ${ }^{31}$. Jak trafnie bowiem zauważył Wojewódzki Sąd Administracyjny w Olsztynie w wyroku z dnia 10.11.2009 r. $^{32}$ ustawa o ochronie przyrody wymaga, by rozważając $\mathrm{z}$ jednej strony wymogi związane $\mathrm{z}$ ochroną przyrody, a z drugiej strony potrzeby inwestycyjne organ starał się wyważyć wskazane powyżej elementy. Innymi słowy ustawa umożliwi wycinkę drzew nawet w sytuacji, gdy są one w pełni zdrowe. Warunkiem jednak takiego postępowania jest pewność, że innymi metodami danej inwestycji przeprowadzić się nie da.

30 Zob. m. in. wyrok WSA w Poznaniu z 10.03.2009 r., sprawa o sygn. akt II SA/Po 823/09 czy też wyrok WSA w Warszawie z 08.09.2009 r., sprawa o sygn. akt IV SA/Wa 923/09 - orzeczenia dostępne w CBOSA.

31 K. Gruszecki, Ustawa..., s. 326.

32 Wyrok WSA w Olsztynie z dnia 10.11.2009 r., II SA/Ol 885/09, dostępne na CBOSA. 
Takie działanie organu administracji publicznej, znajdujące odzwierciedlenie w uzasadnieniu wydanego rozstrzygnięcia, zagwarantuje, że określone postępowanie organu będzie mieściło się w ramach uznania administracyjnego, a nie stanowiło swobodnej, nieopartej na żadnych podstawach, decyzji ${ }^{33}$. Trafny wydaje się przy tym pogląd wyrażony przez Sąd Najwyższy w wyroku z dnia 24 czerwca 1993 r. ${ }^{34}$, w którym to stwierdził, iż przy dokonywaniu sądowej kontroli zgodności z prawem wszelkich decyzji administracji o charakterze uznaniowym (a więc tam, gdzie ustawa daje organowi administracji możliwość dokonywania wartościowania i wyboru jednego spośród różnych dopuszczalnych w świetle prawa rozstrzygnięć) rola, zadania i zakres kompetencji niezawisłego sądu muszą być rozumiane znacznie szerzej i głębiej niż w innych sytuacjach. Mówiąc najprościej, z decyzjami uznaniowymi musi się wiązać nie zmniejszona, lecz zwiększona kontrola sądów, wykonywana z punktu widzenia przestrzegania prawa (i to prawa rozumianego jako całość systemu). Tam bowiem, gdzie większe są możliwości naruszenia lub nadużywania prawa, tam również kontrola sądowa musi być dokładniejsza i bardziej rygorystyczna, a uzasadnienie orzeczenia sądowego - jasne i niebudzące wątpliwości co do jego motywów.

\section{PODSUMOWANIE}

W świetle powyższych rozważań należy zauważyć, iż brak jest w ustawie o ochronie przyrody jednoznacznie sformułowanych dyrektyw upoważniających organy administracji publicznej do wydania zezwolenia na wycinkę drzew lub krzewów. Sformułowane zarówno w judykaturze, jak i w doktrynie poglądy, jakkolwiek stanowią dla organów administracji publicznej niezwykle istotne wytyczne co do przesłanek podjęcia prawidłowego rozstrzygnięcia, to jednak nie są one wiążącymi kryte-

33 Por. wyrok NSA z 11.06.1981 r., SA 829/81, ONSA 1981, nr 1, poz. 57.

34 Wyrok SN z dnia 24.06.1993 r., III ARN 33/93. 
riami, według których organ winien odmówić lub też wydać zezwolenie. Jak podnosi się w doktrynie, taka sytuacja powoduje, że praktyka $\mathrm{w}$ tym zakresie jest bardzo różna, co niekiedy nie sprzyja pewności prawa, a jednocześnie jest konieczne z uwagi na różnorodność życia gospodarczego Dlatego też postuluje się, by przy najbliższej nowelizacji ustawy o ochronie przyrody ustawodawca wprowadził przesłanki, których spełnienie umożliwia np. wydanie zezwolenia na wycinkę ${ }^{35}$. W kontekście nowelizacji u.o.p. można by jednak rozważyć możliwość wykluczenia (a na pewno jego ograniczenia) uznaniowości organu w zakresie udzielania zezwolenia na wycięcie drzew i krzewów poprzez przemodelowanie systemu jego wydawania. Skoro bowiem celem ww. ustawy jest ochrona przyrody, a na gruncie przedmiotowej instytucji ochrona drzew lub krzewów przed ich samowolnym usuwaniem, to czy nie zasadne byłoby wprowadzenie do ustawy prostej przesłanki warunkującej uzyskanie zezwolenia na wycięcie drzewa lub krzewu w postaci rekompensaty polegającej na obowiązku zastępczego nasadzenia. Oczywiście taka możliwość musiałaby podlegać istotnym ograniczeniom związanym chociażby z wiekiem danego drzewa lub krzewu czy też jego gatunkiem. Dodatkowo uzależniając wydanie zezwolenia na wycięcie danego drzewa lub krzewu, należałoby wyposażyć organ w możliwość określania, jaki gatunek winien być zasadzony przez stronę domagającą się wydania zezwolenia. Powyższe rozwiązanie umożliwiłoby jednak ograniczenie uznaniowości organu jedynie do takich przypadków, w których przedmiotem oceny byłyby szczególnie cenne elementy przyrody. Pozostałe natomiast przypadki byłyby przez organ rozstrzygane automatycznie, pod warunkiem zobowiązania się przez stronę do zrekompensowania poczynionych przez nią zmian w otoczeniu.

\section{BIBLIOGRAFIA}

Gruszecki K., Ustawa o ochronie przyrody. Komentarz, Kraków 2005. Gruszecki K., Zezwolenie na usunięcie drzew i krzewów, Wrocław 2011.

35 K. Gruszecki, Ustawa ..., s. 326. 
Jakimowicz W., Wykładnia $w$ prawie administracyjnym, Warszawa 2006.

Jaśkowska M., Uznanie administracyjne w orzecznictwie sadów administracyjnych, „Zeszyty Naukowe Sądownictwa Administracyjnego" 2010, nr 5-6.

Majewski A., Kryteria wydawania przez organy gmin zezwoleń na usunięcie drzew i krzewów, „Samorząd Terytorialny” 1996, nr 1.

Mincer M., Uznanie administracyjne, Toruń 1983.

Ochendowski E., Prawo administracyjne - część ogólna, Toruń 2009.

Radecki W., Ustawa o ochronie przyrody. Komentarz, Warszawa 2008.

Staśkiewicz W., T. Stawecki, Dyskrecjonalność w prawie, Warszawa 2010.

Wróblewski J., Sądowe stosowanie prawa, Warszawa 1972.

Zimmermann J., Znaczenie uzasadnienie rozstrzygnięcia organu administracji publicznej dla orzecznictwa sadowo administracyjnego, „Zeszyty Naukowe Sądownictwa Administracyjnego 2010”, nr 5-6.

Kontakt e-mail:

wojtaczka3@poczta.onet.pl 